\title{
Short Communication: Seed germination, seedling survival and storage behavior of Koompassia excelsa (Leguminosae)
}

\author{
DIAN LATIFAH", FITRI FATMA WARDANI, RIZMOON NURUL ZULKARNAEN \\ Research Center for Plant Conservation and Botanic Gardens, Indonesian Institute of Sciences. Jl. Ir. H.Juanda no. 13, Bogor 16122, West Java, \\ Indonesia. Tel./fax.: +62-251-8322187, `email: latifah2311@yahoo.com
}

Manuscript received: 25 November 2019. Revision accepted: 14 February 2020.

\begin{abstract}
Latifah D, Wardani FF, Zulkarnaen RN. 2020. Seed germination, seedling survival and storage behavior of Koompassia excelsa (Leguminosae). Nusantara Bioscience 12: 46-49. Koompassia excelsa (Becc.) Taub. (Leguminosae) is an important component of many tropical rainforests as an emergent canopy tree. Knowledge and application of germination strategies and increasing seedling survival of this species in many conservation efforts are essential as it is endemic to several areas in Southeast Asia. This research investigated the effects of the different moisture levels of the sowing media on the germination and seedling survival percentage of $K$. excelsa. The seeds exhibited faster germination percentage and higher seedling survival when sown in media with 33.2\%-moisture. The seeds appeared to have intermediate storage behavior. Thus, sowing seeds in 33.2\%-moisture media may promote seedling survival, which is an important part of regeneration as well as conservation of $K$. excelsa.
\end{abstract}

Keywords: Germination, Koompassia excelsa, media, seedling, storage

\section{INTRODUCTION}

Koompassia excelsa is distributed across Southeast Asia, including Indonesia (Sumatera and Borneo Islands), Malaysia, the Philippines, and Thailand. This legume species is well known as The King Tree from Asia, as it can grow to over $80 \mathrm{~m}$ tall, almost $3 \mathrm{~m}$ in diameter at breast height with huge spreading buttresses. The timber is used for furniture and construction. Moreover, the canopy frequently has nested for honey-producing bees. However, although IUCN (2015) assessed $K$. excelsa as 'Least Concern' (LC) which is 'Lower Risk'/conservation dependent ver 2.3 for this species which is restricted in several areas of Southeast Asia. Thus, species conservation efforts are required due to forest die-off phenomenon worldwide. Further, seedling survival under natural and cultivation conditions is reported to be low (Fox 2003). Therefore, more understanding of seed germination and seedling survival of this species is essential for rainforest restoration. Investigating seed storage behavior is required for seed conservation strategies.

There is lack of detailed information on seed germination, seedling survival, seed storage behavior and other biological aspects of $K$. excelsa seeds. Seeds of $K$. excelsa germinated after 6-7 days without pretreatment, since they do not have water-impermeable seed coats (Maid et al. 2014). Funes and Venier (2006) reported that the germination strategy of many species of Leguminosae is connected to the season in which seedling survival is highest. The seed storage behavior of $K$. excelsa is not known (Hong et al 1998), but seeds of K. malaccensis were classified as recalcitrant (FAO 1989) or possibly as orthodox (Sasaki 1976, Sasaki 1980), K. excelsa seeds have been cryopreserved successfully for long-term storage (Azman 2015) indicating the seed storage behavior was intermediate.

These research objectives were to determine (1) the effects of moisture level of the germination substrate on germination and seedling survival and (2) the seed storage behavior. The hypotheses were: (i) Germination will differ under four treatments: (1) 42.6\%-moisture media; (2) $33.2 \%$-moisture media, (3) 12.1\%-moisture media and (4) 5.0\%-moisture media; (ii) Seedling survival will differ under the same four treatments; (iii) seed storage behavior is intermediate.

\section{MATERIALS AND METHODS}

\section{Seed source}

Seed source was a 102-year-old $K$. excelsa tree (accession number: B1914129) growing in Bogor Botanic Gardens, Java Island (West Java), Indonesia (location: I.I.58A). This plant collection originated from a seed collected by E.F. de Vogel in Borneo Island. Both yellowish-to-reddish green and brown fruit were harvested during one-month seed dispersal period in March 2015. The mature fruits were collected in the second week of March. The seeds were not extracted from the fruit as the ripened fruit is indehiscent; however, the peripheral wings were pruned. The mass of fresh seeds (not extracted from the fruit with pruned wings) from ripened fruit was $0.65 \pm$ $0.09 \mathrm{~g}$ on average (10 samples) and the ripened fruit was brown. 


\section{Water imbibition}

The imbibition was conducted to provide fully-imbibed seeds before sowing. Seeds were soaked in distilled water in glass jars for 24 hours in three replicates contained 10 seeds each. The imbibition took 24 hours at $30{ }^{\circ} \mathrm{C}$ (ISTA 2015). The seeds were weighed before and after the imbibition. The fully-imbibed seeds absorbed $5.77 \pm 0.38$ mg water/10 seeds.

\section{Germination experiment}

The germination experiment used a completely randomized design. The seeds were not extracted from the fruit as the ripened fruit is indehiscent; however, the peripheral wings were pruned. Seeds were sown in polybags. Only one seed was sown in each polybag. To obtain a fairly uniform environment, bags were placed under the shade of a tree. Fox (2003) suggests that the germination of many legumes under forest conditions may also be rapid. Thus, this germination experiment using media/substrates that were at moisture contents of: (1) 42.6\%-moisture media consisting of compost; (2) $33.2 \%$ moisture media consisting of sawdust; (3) 12.1\%-moisture media consisting of rice husk and (4) $5.0 \%$-moisture media consisting of sand manipulating various moisture levels of substrates in the forests. The determination of the moisture level of the media was used gravimetric analysis method. Media was watered once a day with an amount of water that was approximately sufficient to maintain the media moisture. There were three replicates of 10 seeds for each moisture level making up 30 polybags for each moisture level. Germination was defined by the appearance of the radicle. Germination was measured by observing the following variables: Germination capacity $(\%)$, coefficient of germination rate, coefficient of germination simultaneity, time to first germination (day) and time to final germination (day). After two months, the seedling survival was determined.

The formula of germination capacity is as follows:

$$
\text { Germination capacity }(\%)=\frac{n}{N} \times 100 \%
$$

Where: $\mathrm{n}=$ number of germinating seeds; $\mathrm{N}=$ total number of seeds sown

Coefficient of germination rate is calculated as:

$$
\text { Coefficient of Germination Rate }=\frac{\Sigma \mathrm{n}}{\Sigma(\mathrm{txn})} \times 100
$$

Where: $\mathrm{n}=$ number of germinating seeds; $\mathrm{t}=$ day when the seeds germinating

Coefficient of germination simultaneity is calculated as:

$$
\begin{aligned}
& \text { Coefficient of germination simultaneity }=\frac{\sum \mathrm{n} \times 100,}{\Sigma\left\{(\mathrm{T}-\mathrm{t})^{2} \cdot \mathrm{n}\right\}} \\
& \text { Where: } \quad \mathrm{T}=\frac{\sum(\mathrm{txn})}{\Sigma \mathrm{n}}
\end{aligned}
$$

$\Sigma \mathrm{n}=$ total number of germinating seeds; $\mathrm{t} \times \mathrm{n}=\mathrm{n}$ seeds germinating when day-t

\section{Seed storage behavior assessment}

The moisture content of seeds is stated as a percentage of fresh weight. The seeds were not extracted from the fruit as the ripened fruit is indehiscent; however, the peripheral wings were pruned. The initial moisture contents of the seeds were $7.04 \pm 0.44 \%$. The seeds were desiccated/dried at $16 \pm 2{ }^{\circ} \mathrm{C}(65 \pm 5 \%$ Relative Humidity) to determine the drying rate. The drying rate to reach $5.98 \%$ moisture content was determined, after which the seeds were stored in three storage treatments conditions: (i) moist storage using moist moss in darkness at $16 \pm 2{ }^{\circ} \mathrm{C}(65 \pm 5 \%$ Relative Humidity), (ii) dry storage using sealed-tight glass jar at ambient room and (iii) $-20{ }^{\circ} \mathrm{C}$ freezer to investigate whether the seed storage behavior performed as recalcitrant, intermediate or orthodox. These treatments were used by considering the storage experiment under several combinations of temperatures to investigate many tropical seed storage behaviors (Berjak and Pammenter 2008). After 1 and 2 months of storage, germination was tested by sowing the seeds in the greenhouse (three replicates; using available media: 5.0\%-moisture and $12.1 \%$-moisture).

\section{Data analysis}

Imbibition and drying rates were analyzed using tstudent test. Germination capacity, coefficient of germination rate, coefficient of germination simultaneity, time to first germination, time to final germination and seedling survival were compared with analysis of variance (ANOVA) at 0.05 confidence level followed by Tukey's test to determine the significant treatment effects. When the data were not normally distributed, the Kruskal-Wallis nonparametric test was applied. Statistical Tools for Agriculture Research (STAR) package was used for all the analyses.

\section{RESULTS AND DISCUSSION}

\section{Results}

The germination rate of $K$. excelsa was affected by the different moisture levels of sowing media (Figure 1). Thus, the results support the first hypotheses. However, the germination capacity and germination simultaneity of $K$. excelsa was not affected by the different moisture levels of sowing media. The germination capacity was $94.2 \pm 1.4 \%$ on average at fast rate $36.1 \pm 2.9 \%$ on average; the highest germination rate 44.93 (Figure 1). The seeds germinated with low simultaneity $15.5 \pm 1.7 \%$ on average. Time to first germination was $2.2 \pm 0.04$ day and time to final germination was $4 \pm 0.2$ days.

Seedling survival will differ under the same four treatments which support the hypotheses. The highest seedling survival occurred in $33.2 \%$-moisture media consisting of sawdust i.e. $79.6 \pm 5.8 \%$ after two months (Figure 2).

The seed storage behavior is intermediate which supports the hypotheses. This was based on the results of the following assessment. The drying rate reached $5.98 \pm$ $0.17 \%$ moisture content (MC) within 8 days which was fast 
(Figure 3). Based on this drying rate, seeds were not recalcitrant. The seeds were also not orthodox as none of the seeds stored in $-20{ }^{\circ} \mathrm{C}$ survived after 1 month was evident. Seed germination capacity of seeds stored in moist-moss at $18 \pm 2^{\circ} \mathrm{C}$ dropped to $17.8 \%$ (5.0\%-moisture media) and none germinated (12.1\%-moisture media) after
1 month. While those stored in the ambient temperature under dry storage resulted in $53.3 \%$ (12.1\%-moisture media) and $13.3 \%$ germination (5.0-moisture media) after 1 month; then dropped to $57.8 \%$ (12.1\%-moisture media) and $35.6 \%$ (5.0\%-moisture media). The seeds appeared to be intermediate.

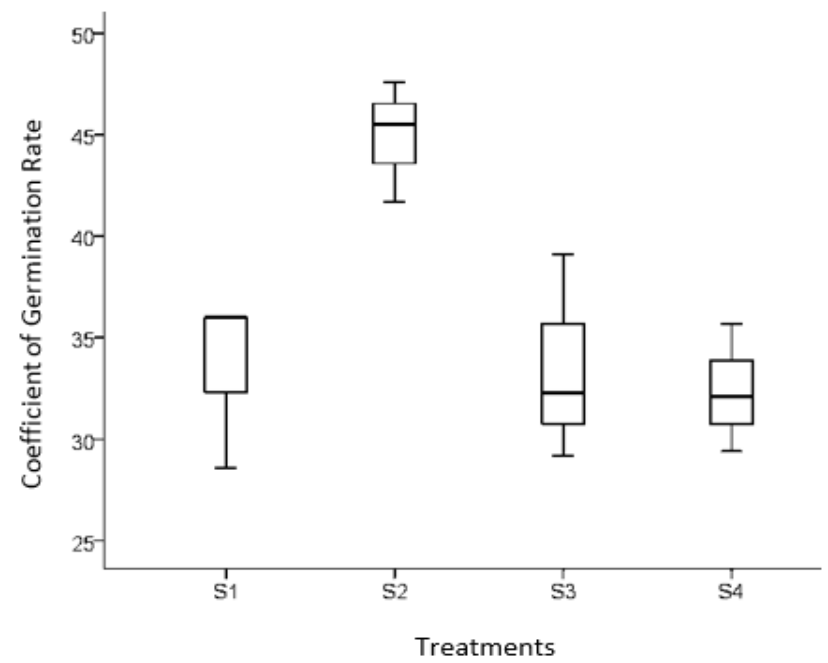

Figure 1. Seed germination rate of brown fruit (mean \pm SEM) under different sowing media; $\mathrm{S} 1=42.6 \%$-moisture , $\mathrm{S} 2=$ $33.2 \%$-moisture, $\mathrm{S} 3=12.1 \%$-moisture and $\mathrm{S} 4=5.0 \%$-moisture media (Tukey, $P<0.05$ ).

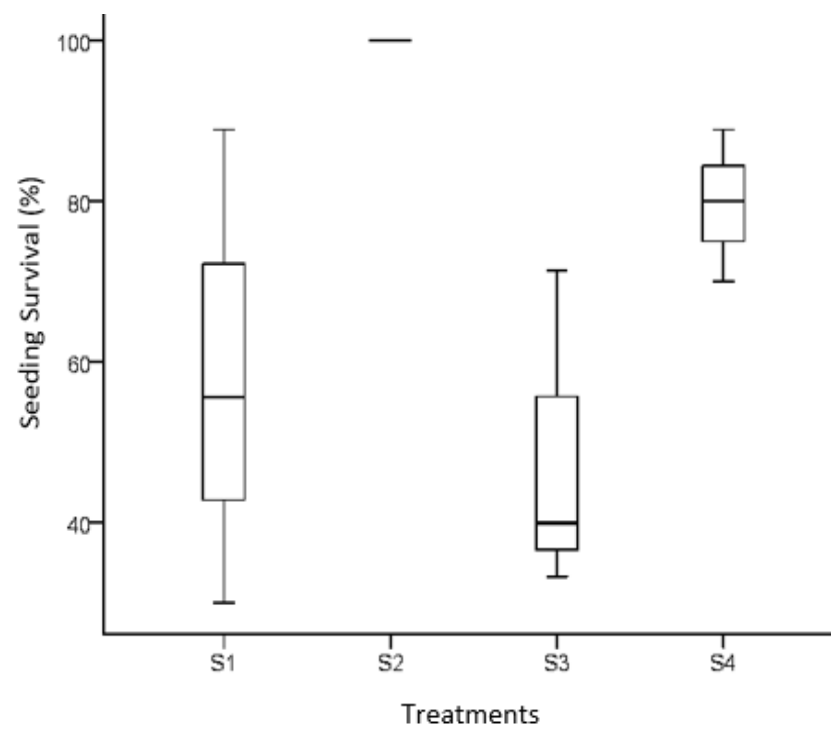

Figure 2. Seedling survival (mean \pm SEM) under different moisture level of sowing media; $\mathrm{S} 1=42.6 \%$-moisture, $\mathrm{S} 2=$ $33.2 \%$-moisture, $\mathrm{S} 3=12.1 \%$-moisture and $\mathrm{S} 4=5.0 \%$-moisture media (Tukey, $P<0.05$ ).

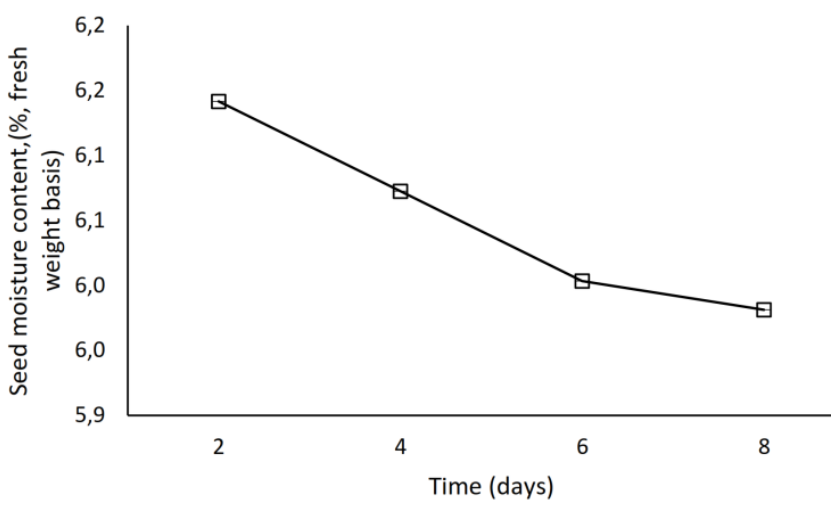

Figure 3. Time course of moisture loss during drying $(P<0.05$; tstudent test)

\section{Discussion}

Koompassia excelsa (Becc.) Taub. (Leguminosae), as eminent canopy trees and house of honey bees with long life span (hundred years old) has played important ecological roles in many tropical rainforests. The germination strategies were essential as the early life stage in many trees regeneration including $K$. excelsa. Germination requires an appropriate environmental condition such as the moisture of the germination substrates (Baskin and Baskin 2014). This research suggests that the germination of $K$. excelsa required moist germination substrates i.e. 33.2\%-moisture media consisting of sawdust. Many crop species required a certain minimum species-specific moisture content in the germination substrates in a closed container such as a petri dish to be attained before they will germinate e.g. soybeans, 50\%; sugar beets, $31.0 \%$; and rice $26.5 \%$ (Hunter and Erickson 1952). This research also suggest that the highest seedling survival occurred in $33.2 \%$-moisture media consisting of sawdust after two months. This is supported by the results shown by previous studies e.g. the moisture levels of substrates or soils surrounding the parent trees may affect the seedling survivorship (Alvarez and Banuet 1998), although Navarro and Guitian (2003) suggest that the seedling survival was affected by the microclimate. The seeds of $K$. excelsa are intermediate. Azman (2015) confirmed that $K$. excelsa seeds have been cryopreserved successfully for long-term storage indicating the seed storage behavior was intermediate that could not be preserved in $-20{ }^{\circ} \mathrm{C}$ cold room. On the other hand, FAO (1989) classified the other species $K$. malaccensis as recalcitrant and Sasaki (1976) and Sasaki (1980) classified 
it as (possibly) orthodox. In nature, this may imply that the potentially-intermediate seeds which may be able to survive under shade or open area with ambient temperature may maintain the viability of the seeds to detect the favourable condition to germinate as well as to yield more survived seedlings.

\section{ACKNOWLEDGEMENTS}

This research is funded by the Indonesian Institute of Sciences (LIPI, Lembaga Ilmu Pengetahuan Indonesia). We thank LIPI Botanic Gardens Seed Bank (NurseryRegistration Department) and Herbarium Bogoriense for their expertise, facilities, resources and staff (Dr. D. Afriastini, Arief Noor Rahmadianto, Aulia, Harto, Mimin, and Tikno) assistances as well as Arif Budiyanto (Soil Physics Analysis Laboratory, Soil Research Department, Ministry of Agriculture, Bogor).

\section{REFERENCES}

Alvarez HG, Banuet AV. 1998. Germination and early seedling growth of Tehuacan Valley cacti species: the role of soils and seed ingestion by dispersers on seedling growth. J Arid Environ 39:21-31.

Azman NZN. 2015. The seed technology laboratory. FRIM in Focus, December, 2-3.
Baskin CC, Baskin JM. 2014. Seeds: Ecology, Biogeography, and Evolution of Dormancy and Germination. 2nd ed. Elsevier/Academic Press, San Diego.

Berjak P, Pammenter NW. 2008. Review: From Avicennia to Zizania, seed recalcitrance in perspective. Ann Bot 101: 213-218.

FAO. 1989. FAO Panel of Experts on Forest Gene Resources, Seventh Session, 4-6 December 1989. FAO, Rome.

Fox JED. 2003. Constraints on the natural regeneration of tropical moist forest. For Ecol Manag 1: 37-65.

Funes G, Venier P. 2006. Dormancy and germination in three Acacia (Leguminosae) species from central Argentina. Seed Sci Res 16: 7782.

Hong TD, Linington S, Ellis R H. 1998. Compendium of Information on Seed Storage Behaviour. The Trustees, Royal Botanic Gardens, Kew, UK.

Hunter JR, Erickson AE. 1952. Relation of seed germination to soil moisture tension. Agron J 44: 107-109.

ISTA. 2015. International Rules for Seed Testing. International Seed Testing Association, Bassersdorf, Switzerland.

IUCN. 2015. Asian Regional Workshop (Conservation \& Sustainable Management of Trees, Viet Nam, August 1996): Koompassia excelsa. The IUCN Red List of Threatened Species 1998: e.T33208A9765707. DOI: 10.2305/IUCN.UK.1998.RLTS.T33208A9765707.en

Maid M, Kodoh J, Mojiol AR. 2014. Koompassia excelsa. Enzyklopädie der Holzgewächse: Handbuch und Atlas der Dendrologie. John \& Sons, Inc., Hoboken, USA.

Navarro L, Guitian J. 2003. Seed germination and seedling survival of two threatened endemic species of the northwest Iberian peninsula. Biol Conserv 109: 313-320.

Sasaki S. 1976. The physiology, storage and germination of timber seeds. In Chin HF, Enoch IC, Raja Harun RM (eds) Seed Technology in the Tropics. Universiti Pertanian Malaysia, Serdang, Malaysia.

Sasaki S. 1980. Storage and germination of some Malaysian legume seeds. Malays For 43: 290-308. 